\title{
Efficacies of the Kenya Education Management Institute Induction Course in the Management of Public Primary Schools in Kenya
}

\author{
Ongoto Joel \\ PhD Student, Kenyatta University \\ Dr. Martin Ogola \\ Lecturer, Kenyatta University, Department of Educational Management Policy and Curriculum Studies \\ Prof. Joseph Malusu \\ Associate Professor of Education, Mwenge Catholic University
}

\begin{abstract}
In order to address performance gaps in management of public primary schools and provision of quality education, the Ministry of Education periodically supports head teachers of primary schools to undertake induction courses in education management. One of the many induction courses supported and organised by the Ministry of Education (MoE) is the Induction Course in Educational Management (ICEM). ICEM is organised by Kenya Education Management Institute (KEMI) for head teachers of public primary schools where they are taken through best management practices to be adopted and implemented in schools. Despite the head teachers undertaking this induction courses, poor management of public primary schools is a perennial problem in many schools. Despite the enormous resources set aside by the Government of Kenya (GoK) for induction courses, poor management of primary schools affects the provision of quality education. The purpose of this study was to investigate the efficacies of ICEM in-service training in order to establish its impact on management of public primary schools in Nairobi County. The specific objective of this study was to examine the procedures used in the selection and preparation of head teachers for ICEM in-service training. The study was anchored on Quality Management System's theory.The study employed a descriptive research design. The target population for the study were public primary schools head teachers, chairpersons of Boards of Management (BOM), senior teachers, subordinate staff members, school prefects and KEMI staff trainers. Stratified random sampling was used to select the target population for this study. Data for the study was collected using structured questionnaires and was analysed using the Statistical Package for Social Sciences (SPSS) computer software. This study established that despite the fact that ICEM training were considered to be pertinent in the management of the schools' resources such as finances, curriculum, plant and human resources, it was revealed that there were no proper policy guidelines on head teacher selection and preparation for ICEM training. The study concludes that time allocated for the trainings were inadequate and lack of follow-ups were challenges that hampered effectiveness of the training. Therefore, this study recommends that the Ministry of Education (MoE) should develop clear policies and guidelines on selection and orientation of head teachers for in-service training. Further, this study recommends that KEMI in partnership with the MoE should review timelines of the trainings and develop a sustainable model of evaluating results or effectiveness of the ICEM training in management of public primary schools in Kenya.
\end{abstract}

Keywords: Efficacy, Education Management and Induction

DOI: $10.7176 / \mathrm{JEP} / 10-18-04$

Publication date:June $30^{\text {th }} 2019$

\subsection{Introduction}

The need to improve the quality of management in schools remains high on the agenda of governments all over the world (United Nations Educational Scientific and Cultural Organization, 2013). The agenda of improving management practices of schools has been triggered by turbulent environments which compels modern organizations, including learning institutions to conform to such environmental changes hence calling for the managers of the schools to be responsive and innovative on organizational management practices (UNESCO, 2013; Pearce \& Robinson, 1997). It is now widely accepted that managers in education require specific preparation if they are to be successful in leading schools and colleges.

The development of effective leaders and managers requires a range of strategies, including high-quality courses and training (Foskettand, 2002). According to Kenney and Reid (1988), training which impacts on management is an integral part of the work and development of an organization. This is because an organization's human resources are among its most important assets that drive management. Training leads to motivation of workers which is very crucial to the success of any organization. Lynton and Pareek (2000) 
acknowledge that training has become the most important and urgent task in modern management. They observe that dissatisfaction with training is growing and that there is reluctance to send staff for training because of lack of positive impact.

Globally, Brundrett (2013) in the United States and Cowie and Crawford (2007) in Canada and Ontario Principal's Council (2013) in Canada assert that the drastic decline in performance of instituions of higher learning and more specifically in public primary schools was attributed with inappropriate formal trainings which were tailored towards transactional administration but not transformational administration and management. Regionally, Theobald, et al (2007) in Nigeria opine that trainings of head teachers in public primary schools had a significant positive effect on performance of the schools in terms of resource management such as funds, employees, information and technology. Subsequently in Uganda, Kayiwa (2011) acknowledges that despite the minimum entry requirement of teachers in the service, deteriorating performance of public primary school was an issue of concern. By extension, KEMI (2012), MoE (2007), Omote (2005), Ministry of Education and Human Resource Development, 1999 point out that despite the effort of the government to improve the quality of education in public primary schools in Kenya though induction trainings for head teachers, still issues of school management were of great concern which need to be investigated.

Despite the mandate of KEMI to offered induction Course in Educational Management (ICEM), Senior Management Induction Course for Educational Personnel (SICEM), a Professional Certificate Course in Educational Management (PCEM) and a Training of Trainers in Educational Management course (TOTEM), it is noted by the KEMI (2012) that there was little impact on management primary schools in Kenya. Relevance and effectiveness of the induction trainings of schools' head teachers is still an area that need to be relooked into to establish a sustainable training model that can match skills and challenges experienced in public primary schools. With increased expenditure by the government on annually for the period between 2006-2018 on in-service training of head teachers, little has been achieved in terms of effective management of schools (KEM, 2012). Similarly, Kalai (2012) attests that with changes in the educational sector, development of capacity is considered to be the pertinent factor that can promote transformational change in public schools in Kenya. Transformational changes can be attributed to effective utilization of financial resources, minimal cases of unrest or strikes and improved academic performance of students (MoE, 2013).

Based on the proposed changes of the curriculum, in-service trainings are conceptualized to facilitate effective implementation of the new policies of the ministry of education. Without appropriate skills and knowledge among head teachers of public schools in Kenya, it will be an uphill task to achieve objectives of the new system of education in primary schools in Kenya (Githu, 2014). Therefore, it is on this background this study was motivated to establish efficacies of ICEM on the management practices of head teachers of public primary schools in Nairobi County.

\subsection{Statement of the Problem}

Effective execution of management function is viewed to be a function of appropriate knowledge, skills and attitudes among heads of public schools in Kenya though there exist deficiencies in evidence on the link between efficacies of ICEM on the management practices of head teachers of public primary schools in Kenya (MoE, 2009). Effective management in public primary schools in Kenya is demonstrated by participatory leadership, effective utilization of schools resources such as money, employee development, time management, parent and student involvement in key decisions (Kalai, 2012). Despite the fact that the Government of Kenya made it mandatory that all head teachers in public primary schools undertake ICEM in-service training in order to improve their efficacy in the management of their schools, it is noted that by the MoE (2014) that majority (81\%) of the primary schools in Kenya are underperforming despite in-service trainings attended by school head teachers.

Similarly, it is acknowledging by Githu (2014) that despite mandatory ICEM trainings attended by head teachers, most the public primary schools in Kenya are experiencing deteriorating performance. Challenges such as inability to implement new policies of the ministry of education, resource utilization, capacity development, unsatisfactory academic performance pupils and inability to engage key stakeholders in decisions are some of the factors which have hampered public primary schools from achieving the intended objectives of the ministry of education in Kenya. Even though extensive studies have been conducted by MoE (2014), Githu (2014), Kalai (2012), International Monetary Fund (IMF) (2012), Wachira (1996) Wambua (2004), Ngure (2007) and Kalai (1999), it is noted that there was no clear understanding on the link between efficacies of ICEM on the management practices of head teachers of public primary schools thus the need to focus on Nairobi City County to bridge the knowledge gaps in this area.

\subsection{Objective of the Study}

To examine the procedures used in the selection and preparation of head teachers for ICEM in-service training. 


\subsection{Literature Review}

In the US education system, the process of training school heads and other teachers involved in the management of schools is considered a serious issue. This is because these heads are solely responsible for the success or failure of the schools they are entrusted to manage. Pont, Nusche and Moorman (2008) posit that school leadership is important in the education policy agendas globally. This is due to the fact that it plays a significant part in refining of school results by manipulating the impetuses and teacher aptitudes, as well as the school environment and setting. Pont, et al., (2008) further noted that there has been an urgent need for the countries to adapt their education systems to the requirements of the modern society. Head teacher preparation, therefore, is a vital step towards the realization of this task. Numerous countries have moved towards decentralization of administration which has made schools more autonomous in their decision making and holding their managers more accountable for the results. Most countries have come to the realization that the quality of their people depends on the education and training they have. Therefore, there is a dire need to improve the quality of training and service given to teachers especially those that head schools.

School heads in Britain are usually exposed to rigorous management and financial training. The British government believes that the training helps them become better managers. The practice is similar in Wales and Scotland where in-service trainings and courses for school heads are common (Organization for Economic Cooperation and Development, 2009). This explains the high quality of school management in these countries compared to that of developing countries like Nigeria, Kenya, Uganda and Cameroon.

Cowie \& Crawford (2007) sought to determine whether principal preparedness in schools was still an act of faith or just a policy. This study analysed the principal preparation concerning management practices in Scotland and England. The main objective of the study was to find out effectiveness of the current preparations of school head teachers in Scotland and England. Cowie \& Crawford (2007) found out that in Scotland, the issue of principal preparation was not effective in realizing the goal of proper school management. This was attributed to the fact that most principals and school heads considered the training as just a formality and thus did not transfer what they learned from the courses to the actual school settings. Bayrakci (2009) in a qualitative research conducted in Turkey investigated in-service training activities in the two education systems (Japan and Turkey) through visits to the educational institutions and semi-structured interviews. The study found out that problems facing in-service training activities in Turkey was lack of professional staff, no collaborative partnerships between teachers, no provision for feedback and no systematic in-service training models. The study noted that although there were various in-service training activities in Turkey at both the national and local levels, these activities were far from providing an effective system of professional development and did not contribute to teachers' lifelong learning. Teachers and administrators in Turkey were not motivated to participate in in-service training activities because of the ineffective nature of these activities. On the other hand, some of the features of in-service training in Japan, such as the existence of systematic training activities and the use of web-based communication systems and satellite systems for these activities, provided good examples for Turkey.

Bayrakci (2009)'s study gave impetus to this study since it confirmed the need to examine efficacies of inservice training. Though this study benefitted greatly from Bayrakci (2009)'s study, it adopted a quantitative paradigm and collected data on the nature, perceptions and impact of ICEM. In Nigeria, the training and preparation of school heads has not been granted any serious consideration in the country's educational policies. There is a general belief among Education administrators that experienced teachers could be easily promoted to become school heads even without undergoing any training (Arikewuyo, 2009). This is a dangerous trend as it assigns serious responsibilities to teachers who might not have any idea of what management is all about. According to Arikewuyo (2009), the education policies in Nigeria hold little regard to in-service training and preparation of heads of schools thus the poor state of management in most Nigerian schools especially secondary schools. Most schools in the country are run by un-trained heads who were promoted to heads based on their experience in teaching. The lack of adequate in-service training and preparation courses has seen the mismanagement of these schools resulting to loss of government funds and poor results in these schools.

Morrant (2011) points out that in-service training is taken to include all those activities and courses in which a serving head teacher may participate in for the purpose of extending his professional knowledge, interest or skill preparation for a degree, diploma or other qualification subsequent to initial training is included within this definition. Javis (2010) observes that in-service education is continuing education given to principals' during the cause of their working-lives, which may be in the house. It may also take the form of block release or even secondment (Sadtu, 2004). In-service training is intended for already qualified teachers to retrain or given specialized areas of training in areas of school life such as curriculum related in-service training designed to introduce teachers to innovations taking place in the curriculum of schools or to help implement educational reforms (Kamindo, 2008). Clearly, from the foregoing it can be inferred that, in-service education and training can be seen as training that is conducted at any time after an individual has been employed as a full time head teacher (Adentwi, 2010). This forms the context upon which ICEM in-service training was developed and offered by Kenya Education Management Institute (KEMI). 
The National Handbook for 2000 and beyond on Education for All (EFA) in Kenya asserts that the MoE undertook to train head teachers in institutional management especially in financial management (MoEST, 2001). This in-service training recommended was to be performed by KEMI. Although the GoK had been training head teachers at KEMI on financial management no study was available comparing those who had attended financial training courses and those who had not attended such courses performed their work. The Government of Kenya undertook to provide globally competitive quality education; training and research. This could only be achieved with properly trained managers for primary schools in Kenya (Ministry of Planning and National Development, 2007). It was important that KEMI induction courses were evaluated bearing in mind the benefits derived from evaluation of programmes in education in a study like this. The development and implementation of a comprehensive in-service programme for all teachers ensured that competent teachers are appointed as head teachers of schools and that their performance and promotion is monitored through an established system (MoEST, 2003

Derek (1999) asserts that a superior manager must possess various administrative competencies. This is the ability to do problem analysis, which involves the ability to seek out relevant data and analyse information to determine the important elements of a problem situation. The school manager must search for information with a purpose and have ability of judgment. The school manager must reach logical conclusions and make high quality decisions based on available information. The school manager must have the skill of identifying educational needs and setting priorities. The school manager must have the ability to evaluate critically written communication. A school leader must possess organizational ability, which involves the ability to plan, schedule and control the work of others, skills in using resources in an optimal fashion and ability to deal with a volume of paperwork and heavy demands on one's time. The school leader must be decisive. This is the capability to know when a decision is required and to act swiftly (Derek, 1999).

Greenland (2003) observes that on-the-job or in-service training is an indispensable aspect of the teachers' professional development. Greenland indicated that most of the training sessions that teachers have been attending over the years have no relevance in the classroom situation, and hence the abysmal performance of some teachers. Training in organizations may be used to improve management skills and performance of staff (MoEST, 2005). Training enables organizations to increase the quantity and quality of their outputs. Training creates a pool of qualified personnel in organizations, improves morale of workers, improves job satisfaction, motivates and attracts the most needed personnel in an organization. Training prevents work - related accidents, reduces outmoded behaviour, creates personal growth and reduces the problems associated with management of employees (Okumbe, 2001).Wachira (1996), Malusu (1997), Kalai (1998), Onyango (2001) acknowledge that in-service training among head teachers of public schools in Kenya are of significant importance despite internal and external forces that influence performance of public schools directly or indirectly.

According to Cole (2004), evaluation of training is part of the control process of training. Evaluation methods aim to obtain feedback about the results or outputs of training, and to use this feedback to assess the value of the training, with a view to improvement, where necessary. Training evaluation is concerned with setting appropriate standards of training. The more precise the standards set, the easier it is to evaluate the success of training. Evaluation can take place at a number of different levels, ranging from immediate to longterm results. Each level requires a different evaluation strategy.

\subsection{Methodology}

Descriptive research design was adopted to establish the problem under investigation. Descriptive research design was considered appropriate based on the fact that it facilitated discovery of new knowledge, data was analysed and presented quantitatively, data was collected from a sizeable population with homogenous characteristics.

The target population of this study were 96 ICEM in-service trained public primary school head teachers, and their respective senior teachers, heads of support staff, head prefects, Board of Management (BOM) chairpersons as well as KEMI ICEM staff trainers.

Stratified random sampling technique was used to select respondents. The sample size of this study comprised 149. The sample size was determined using Watson (2001) formula. The specific respondents of the study were Public primary head teachers, Senior teachers BOM chairpersons, head prefects, heads of support staff and KEMI full-time staff trainers.

Structured questionnaires were used for data collection in this study. Further, document analysis method was used to review published documents such as ICEM modules, KEMI policy guidelines, training materials and MoE guidelines.

Data was analysed descriptively with the help of Statistical Package for Social Sciences (SPSS) version 19 software was used. Qualitative data obtained from open ended questions and published content was reviewed using document analysis method. 


\subsection{Research Findings and Discussions}

The researcher distributed a total of 379 questionnaires to respondents drawn from the 72 schools whose head teachers had undergone ICEM in-service training and was able to receive 374 questionnaires. Apart from head teachers, questionnaires were also distributed to senior teachers, BOM chairpersons, heads of support staff and school head prefects.

Table 4.1: Head teachers' attendance of ICEM training at KEMI

\begin{tabular}{lll}
\hline Response & Frequency & Percentage \\
\hline Yes & 72 & 100 \\
Total & $\mathbf{7 2}$ & $\mathbf{1 0 0}$
\end{tabular}

Findings in table 4.1 indicate that $100 \%$ of the head teachers who participated in this study had attended KEMI ICEM training and therefore were well equipped to head their respective primary schools and also to participate in the study. This finding imply that key respondents, the head teachers, were informed on issues regarding academic management and in a position to respond to the issues regarding effective management practices in public primary schools.

From the theoretical framework, modern day training in the work place is designed to provide trainees with knowledge and skills needed for their current jobs and is considered as an investment in human capital (Deming, 2000). Such investment not only creates competitive advantage for an organization, but also provides innovations and opportunities to learn new technologies and improve employee skills, knowledge and firm performance. It is as a result of this realization that institutions such as the Ministry of Education, through KEMI, regularly offer in-service training to school heads in order to equip them with skills that are tailored to make them execute their mandates effectively and efficiently by capacity building them on leadership and other aspects of school management.

It is important to note that KEMI training was made compulsory in 2011 and all education administrators are required to train (MoEST, 2011). This is based on the realisation that through training, education administrators such as head teachers gain knowledge and skills required for quality school management hence quality leadership. This position is supported by Keith and Francoise (2001), who in a study on financing secondary education in developing countries, point out the fact that the quality of education depends on the way the school is managed and the quality of management and leadership provided by the head teacher.

Table 4.2: Number of times each head teacher attended ICEM training

\begin{tabular}{lcc}
\hline Attendance Rate & Frequency & Percentage \\
\hline Once a year & 34 & 47.2 \\
Twice a year & 22 & 30.6 \\
Thrice a year & 16 & 22.2 \\
Total & $\mathbf{7 2}$ & $\mathbf{1 0 0}$
\end{tabular}

Findings in table 4.2 indicate that more than half of the head teachers $(52.8 \%)$ had attended training either twice or three times a year while $47.2 \%$ of them have attended once. In undertaking training for more than once a year indicates that the head teachers are keen on improving their competencies and skills in the administration and management of their schools through regular in-service training.

The findings concur with those of Githu (2014), who in a study on factors influencing the perception of effectiveness of Kenya Education Management Institute in-service programs in Nairobi, observes that head teachers are attending more KEMI trainings in order to enhance their competency and gain more knowledge and skills to enable them manage their respective institutions effectively. This observation agrees with the main aim of KEMI programme, which is to ensure that head teachers acquire the skills required carrying out various administrative tasks (Wekhuyi, 2014).

Table 4.3: Head teachers' knowledge of policy guidelines for ICEM training selection

\begin{tabular}{lll}
\hline Response & Frequency & Percentage \\
\hline Yes & 19 & 25.7 \\
No & 35 & 49.3 \\
Not sure & 18 & 25.0 \\
Total & $\mathbf{7 2}$ & $\mathbf{1 0 0}$
\end{tabular}

Findings in table 4.3 indicate that a vast majority of the head teachers $(74.3 \%)$ are not knowledgeable on the policy guidelines regarding their selection and preparation for KEMI in-service training while 25.7\% indicated that they are aware of such guidelines. The findings and in line with that of MoE (2011) which point out that there are no clear guidelines on how the head teachers are selected and prepared to undertake ICEM training. During the individual interview sessions, majority of the head teachers admitted that they only received letters 
informing them for training and the dates it will take place. They also lamented that nobody prepared them for training and therefore they were left at a loss and only complied with the stipulations set out in the invitation letters. This finding concurs with that of Musembi (2016) who, from a study on the influence of KEMI principals' diploma course in education management on management practices of public secondary schools in Matungulu sub-county, lamented that there was no proper preparation of the principals before undertaking the KEMI management course.

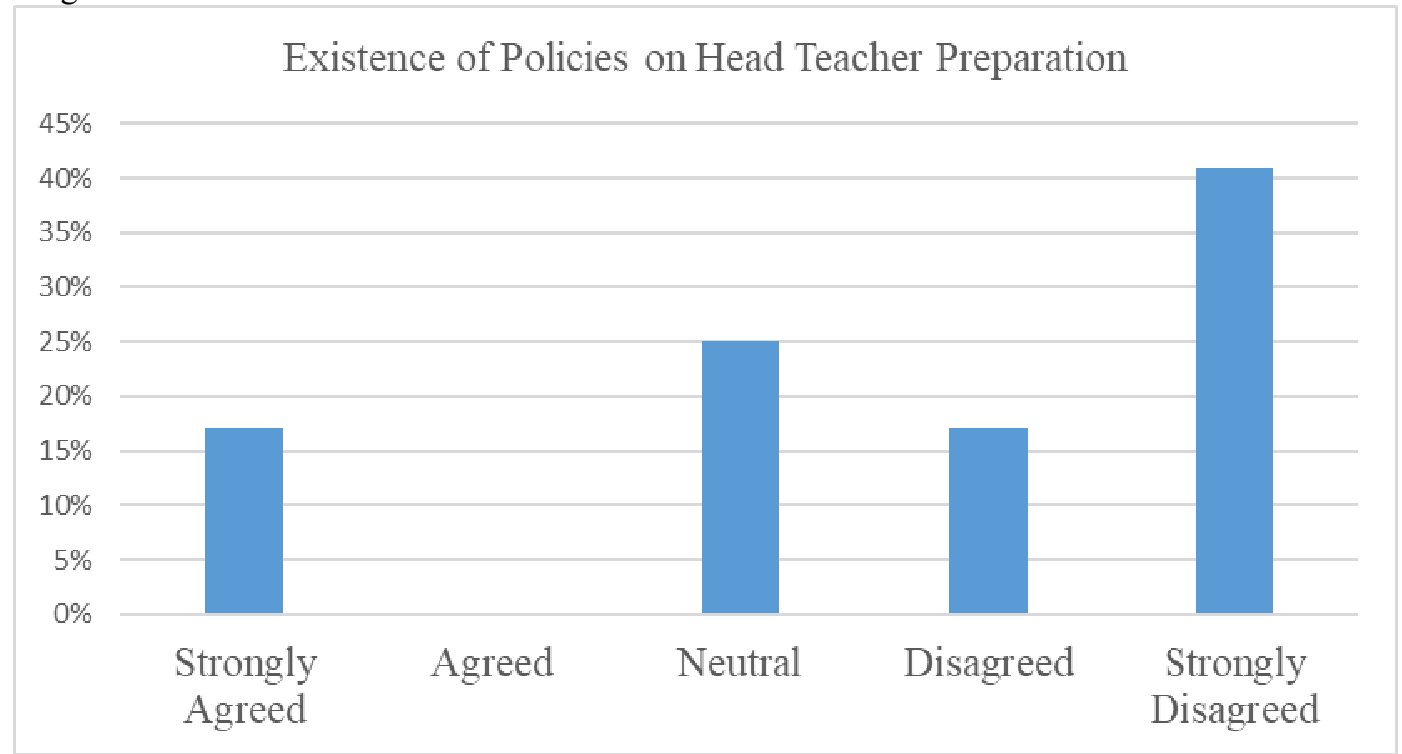

Figure 4.1: ICEM facilitators' views on head teachers' preparation for training

Findings from figure 4.1 indicate that majority of ICEM trainers $(58 \%)$ are in agreement that there exist no clear policy guidelines on selection and preparation of head teachers before embarking on ICEM in-service training. This, therefore, implies that head teachers were simply required to attend training without prior information regarding the importance and scope of such training. This finding are in agreement with the head teachers who observe that they are always required to comply with invitation letters without further details on the scope of the course. These findings are in tandem with those of Morrant (2011), in a study on in-service education within the school, avers that head teacher preparation for any task head is important for the overall success of such task. This is so because the preparation gives them the right frame of mind and orientation to undertake the task.

Head teacher preparation is an important component for the overall success of ICEM in-service training and it functions as an orientation for head teachers to the ICEM course. It involves being taken through the course requirements such as the extent of training, content, scope of each training module, duration of each course, course requirements and expected outcomes. Kalai (2012), in a study on school principals' preparation and development, contends that the orientation of head teachers to the management training course is important because it helps them understand expectations of the entire course. This was considered an important aspect for this study for it not only served to help the trainees set their own personal objectives but also set the tone for the entire training. Thus, the study sought to find out from KEMI facilitators whether they orient the head teachers on ICEM before the commencing the actual training

Table 4.4: Orientation of head teachers on ICEM training

\begin{tabular}{|l|l|l|l|l|l|l|}
\hline $\begin{array}{l}\text { KEMI Staff Trainers } \\
\text { Evaluation of ICEM }\end{array}$ & $\mathbf{N}$ & $\begin{array}{l}\text { Strongly } \\
\text { Agreed }\end{array}$ & Agreed & Neutral & Disagreed & $\begin{array}{l}\text { Strongly } \\
\text { Disagreed }\end{array}$ \\
\hline Value of ICEM after in- service training & 14 & $42 \%$ & $25 \%$ & $8 \%$ & - & $25 \%$ \\
\hline Clarity of preparation guidelines & 14 & $17 \%$ & - & $25 \%$ & 17 & $41 \%$ \\
\hline After training follow-ups & 14 & - & $8 \%$ & $17 \%$ & $42 \%$ & $33 \%$ \\
\hline Training modes of delivery & 14 & $8 \%$ & $25 \%$ & $25 \%$ & $17 \%$ & $25 \%$ \\
\hline Management course offered & 14 & $25 \%$ & - & $25 \%$ & $42 \%$ & $8 \%$ \\
\hline Durations of trainings & 14 & $8 \%$ & - & $25 \%$ & $42 \%$ & $25 \%$ \\
\hline Suitability of learning environments & 14 & $33 \%$ & $17 \%$ & $17 \%$ & $25 \%$ & $8 \%$ \\
\hline Addition of courses by ICEM & 14 & - & $42 \%$ & $42 \%$ & $25 \%$ & - \\
\hline Use of ICEM training & 14 & - & $42 \%$ & $33 \%$ & $16 \%$ & - \\
\hline
\end{tabular}

As shown in Table 4.4, it was established that KEMI facilitators spared little or no efforts on orienting the head teachers on the ICEM in-service training course. $67 \%$ of KEMI facilitators agreed that head teachers are oriented on the value of ICEM. The other aspects such as follow up after training, mode of delivery, units 
offered, and duration of course among other aspects fair dismally in the orientation of the head teachers. This implies that head teachers are taken straight to in-service training without adequate orientation and preparation for the course.

This lapse could be attributed to managing transition as a gap existing in policy guidelines on in-service training for education administrators (Kiio, 2015). Besides orientation, majority $(75 \%)$ of KEMI facilitators pointed out that there were no follow-up mechanisms of the head teachers after ICEM in-service training to ascertain whether they had improved in their performance and they were discharging their duties in accordance to the in-service training expectations. Additionally, $67 \%$ of the facilitators were of the view that ICEM course duration was inadequate while $(42 \%)$ of the facilitators were in agreement that relevant courses were never added to the ICEM curriculum and that removal of irrelevant ICEM units was rarely done.

Overall, it can be said that little effort is put to prepare head teachers to undertake the ICEM in-service training. It can be deduced that effective policy guidelines on head teacher preparation cover areas like performance measurement after in-service training, follow-up on trainees, durations of in-service courses, inservice training environments, and introduction of new courses and removal of obsolete courses. These findings concur with Githu (2014) who, in a study on factors influencing principals' perception of effectiveness of Kenya Education Management Institute in-service programmes in Nairobi County, observes that for the presence of obsolete courses in KEMI in-service training, limitations on the duration of training and absence of structured follow-ups after training negate the intended purpose and impact of in-service training. Further, while writing about school management and role of school heads in Kenya, Onderi and Makori (2013) observe that the lack of effective preparation of school head teachers leaves them feeling like they were "balancing at the top of the grease pole" and as if they were "left to swim or sink." Therefore, in order for ICEM to realise its objectives which aim at enabling school heads to understand, appreciate, expound and implement GoK policies in education and training (MoE, 2011), there is need to include all relevant units, improve on the duration of training, and develop proper structures for follow-ups on the trainees.

\subsection{Conclusions and Recommendations \\ 5.1.1 Conclusions}

This study set out to examine whether the head teachers of public primary schools were properly selected and adequately prepared for ICEM in-service training. In line with this, it was hoped that there were clear policy guidelines that governed the selection and preparation of head teachers for in-service training. Findings from the study showed and indicated that there were no clear policy guidelines on head teachers' selection and preparation for ICEM training. The head teachers observed that they were not oriented on ICEM course requirements, expectations, coverage, modules and durations for each module. Document analysis revealed that existing policy guidelines were silent on the preparation of head teachers for in-service training. Majority of ICEM trained head teachers felt that there was a problem in identifying those to be trained and when to be trained. Invitation letters were never given out at the right time and that not all head teachers invited attended the training. Majority of ICEM trainers observed that there were no proper follow-up structures after training, and that the staff trainers were not sure whether head teachers performed better after attending the courses because there was no evaluation. The findings also established that both the ICEM trained head teachers and staff trainers raised concerns on the duration for in-service training for they felt that the time allocated was not adequate.

\subsubsection{Recommendations}

Based on the findings of this study the following recommendations were made: the MoE should come up with policy guidelines on the selection and preparation of head teachers for in-service training. More information should be disseminated by KEMI about their training programmes to the targeted groups. KEMI should publish the ICEM instructional materials in education management for public primary head teachers. KEMI should improve on tracking of its ICEM trainees for proper evaluation of courses for public primary head teachers. KEMI should ensure that ICEM is relevant and tailored to address the needs of public primary head teachers. KEMI should relook and revise the duration of the ICEM. KEMI needs to carry out ICEM evaluation to determine the worth of some of the course for public primary head teachers and more resources should be set aside by KEMI for research on staff training and development for public primary schools.

\section{References}

Brundrett, M. (2013). "The Development of School Leadership Preparation Programmes in England and the USA: A Comparative Analysis." Sage Journals, 5(2), 1-25.

Bryman, A. (2004). Social Research Methods. Oxford: Oxford University Press.

Cole, A. G. (2004).Management Theory and Practice ( $\left.6^{\text {th }} E d\right)$. London: TJ International, Padstow Cornwall.

Cowie, M. \& Crawford, M. (2007). "Principal preparation - still an act of faith?" School Leadership \& Management, Vol. 27 (2), pp. 129-146.

Derek, E. (1999). Competencies for School Managers. London: Kogan Page. 
Foskett, N \& Hemsley-Brown, J (2002). Choosing futures young people's decision-making in education, training and careers markets. London: Routledge Falmer.

Greenland, J. (2003). The in-service training of Primary school teachers in English-speaking Africa. London: Macmillan Publishers Ltd

International Monetary Fund (IMF). (2012). Kenya: Poverty Reduction Strategy Paper - Progress Report. USA: IMF.

Jarvis, P. (2010). An international dictionary of adults and continuing education. London: Routledge and Kegal Paul.

Kagiri, S. M. (2005). The role of Kenya Education Management Institute in Effective/of heads of secondary schools. Unpublished Master of Education Thesis, Kenyatta University, Nairobi, Kenya

Kalai, J. M. (1998). Kenya Education Management Institute (KEMI), in- service Programs as Perceived by Secondary Schools Head teachers. A case study of Kitui District. Unpublished Masters of Education thesis, University of Nairobi, Nairobi, Kenya.

Kalai J.M. (2012) School principals' preparation and development. Saarbrucken: Lambert Academic publishers.

Kamindo, C.M (2008) Instructional supervision in an era of change: policy and practice in primary education in Kenya, Durham University School of Education United Kingdom, unpublished PhD thesis.

Keith, L. \& Francoise, C. (2001). Financing secondary education in developing countries: strategies for sustaining growth. Published by International Institute for Educational Planning. Paris.

Kenya Institute of Education, (1999). Aids Education Facilitators Handbook. Nairobi: Government Printer.

Kenya Education Management Institute (2008). KEMI News link Briefs. Nairobi. Kenya Education Staff Institute.

Kiio, J.S. (2015). Influence of Kenya education management institute's training on head teachers' competence in management of primary schools in Westlands Sub-County, Nairobi. Unpublished Med. Thesis, University of Nairobi, Nairobi.

Kiminyo, D. M. (1991). Introduction to Educational Statistics. Nairobi: Educational Research \& Publishers Ltd.

Kimosop, M. P. (2002). A study of the role of the headteacher in instructional Supervision in Kabarnet and Salawa divisions of Baringo district. Unpublished Master of Education Thesis, Kenyatta University, Nairobi.

Lynton R. P. \& Pareek U. (2000). Training for Organizational Transformation. New Delhi: Sage Publications.

Malusu, J. M. (1997). The role of the Christian church in curriculum development in Kenya: A case study of CISRET and CREATE in-service teacher education programs. Unpublished. $\mathrm{PhD}$ Thesis, Kenyatta University, Nairobi, Kenya.

Ministry of Education (2007). Strategic Plan 2006 - 2011. Nairobi: Government Printer.

Ministry of Education (2007). Kenya Education Management Institute. Education Management course. A training module for school management Committees for Kenya primary schools. Module 1. Nairobi: $\mathrm{KEMI} / \mathrm{VVOB}$.

Ministry of Education (2013). Kenya Education Management Institute. Education Management course. A training module for school management Committees for Kenya primary schools. Module 2. Nairobi: $\mathrm{KEMI} / \mathrm{VVOB}$

Ministry of Education, Science and Technology (2001). Education for all (EFA), in Kenya National Handbook for 2000 and Beyond. Nairobi: Ministry of Education.

Morant, R. W. (2011). In-service education within the school. London: George Allen \& Urwin.

Musembi, P. M. (2016). The Influence of KEMI Principals' Diploma in Education management Training Course On Management Practices Of Public Secondary Schools in Matungulu Sub-County. Unpublished M.Ed.Project, South Eastern Kenya University

Ngure, D. G. (2007). Impact of In-Service Training on Secondary Head teachers Management Skills in Nyeri. Unpublished Med Project, University of Nairobi, Nairobi, Kenya.

Organization for Economic Co-operation and Development (OECD). (2009). Improving School Leadership the Toolkit. UK: OECD.

Omote, J. M. (2005). Challenges faced by Head teachers in the Management of FPE and how they coped with them in Rigoma Division, Nyamira District. Kenya. Unpublished Med Project, Kenyatta University, Nairobi, Kenya.

Onderi, H and Makori, A. (2013). Secondary school principals in Nyamira County in Kenya: Issues and challenges. Educational Research International, Vol. 1 (1).

Onyango, A. G. (2001). Competences needed by secondary school head teachers and Implications for preservice and in-service education: A case of Nairobi and Kakamega district. (Kenya). Unpublished PhD thesis, Kenyatta University, Nairobi, Kenya.

Pearce, J. A., \& Robinson, R. B. (1997). Strategic Management: Strategy Formulation and Implementation, Instructor's Manual, $6^{\text {th }}$ edition, Chicago, IL, Richard D. Irwin, Inc.,

Pont, B., Nusche, D. \& Moorman, H. (2008). "Improving School Leadership." Volume 1: Policy and Practice. USA: OECD. 
Sadtu, J. S. (2004). School for Adolescents: Staff. Journal of Educational Sociology. Retrieved on August 10, 2013 from www. jstor. Org/stble/1169154.

Theobald, D., Umar, A., Ochekpe, S. \& Sanni, K. S. (2007). "Country profile prepared for the Education for All Global Monitoring Report 2008 Education for all by 2015: will we make it?" UNESCO. Retrieved on $8^{\text {th }}$ January, 2015 from http://unesdoc.unesco.org/images/0015/001555/155589e.pdf Harcourt Brace Jovanovich.

UNESCO (2013). Better Schools: Resource Materials for School Heads in Africa. Retrieved on $28^{\text {th }}$ March, 2016 from http://library.unescoiicba.org/English/Better Schools/Better\%20Schools/MODULE7/module7 unit3.htm

Wachira, J.N. (1996). Preparation of Secondary School Head teachers and Implications on Their Administrative Performance: A Case Study of Nairobi Province. Nairobi. Unpublished M.Ed. Thesis, Kenyatta University, Nairobi, Kenya.

Wambua, P. M. (2004). A Study of Head Teachers Perception towards KEMI In-Service Programmes in Nairobi Province. Unpublished Med Project, University of Nairobi, Nairobi, Kenya.

Wekhuyi, A. S. (2014). "Influence of In-Service Training on Public Secondary School Principals' Management of Finances and Human Resources in Busia County, Kenya." Unpublished Masters Project, University of Nairobi, Nairobi, Kenya. 